\title{
Rewolucja w sercu małego miasta. Rewitalizacja rynku w Osieku
}

\section{A revolution in the heart of a small town. Revitalization of the market square in Osiek}

\section{Streszczenie}

Celem artykułu jest przedstawienie transformacji przestrzeni publicznej, jaka zaszła w wyniku przeprowadzenia procesu rewitalizacji. Problem przedstawiono na przykładzie przekształceń, jakim uległ rynek Osieka, małego miasta położonego w województwie świętokrzyskim. Przedstawiono analizę porównawczą w zakresie dostępności, zagospodarowania funkcjonalno-przestrzennego oraz zagadnień kompozycyjnych i estetycznych w odniesieniu do przestrzeni rynku przed rewitalizacją i po rewitalizacji. Wskazano, że realizacje powstające w wyniku rewitalizacji wpływają na poprawę atrakcyjności miejsca. Odpowiednio zagospodarowane małomiasteczkowe rynki krystalizują układ przestrzenny całej miejscowości, stanowiąc ich wizytówkę, są także silnie związane z poczuciem tożsamości lokalnej mieszkańców.

Słowa kluczowe: rynek, małe miasto, rewitalizacja

\section{Abstract}

The aim of the paper is to present the transformation of public space that has taken place as a result of the revitalisation process. The issue is presented on the example of the transformation of the market square in Osiek, a small town in the Świętokrzyskie Voivodship. A comparative analysis is presented on accessibility, functional and spatial development as well as compositional and aesthetic issues in relation to the market square space before and after revitalisation. It is indicated that the projects created as a result of revitalisation contribute to the improvement of the attractiveness of the place. Properly developed small-town markets crystallise the spatial arrangement of the entire city and are strongly associated with the sense of local identity of the inhabitants.

Keywords: market square, small town, revitalisation 


\section{WSTĘP}

Znaczenie placu w małym mieście zawsze było istotne. W ośrodkach miejskich liczących nie więcej niż 20 tys. ${ }^{1}$ mieszkańców, o genezie średniowiecznej lub renesansowej, rzadko pojawiała się więcej niż jedna tego typu przestrzeń2. Wyjątkową rolę, jaką spełniały małomiasteczkowe rynki, przedstawiają autorzy w licznych publikacjach naukowych. E. Węcławowicz-Bilska (2015), E. Przesmycka (2001, 2009), B. Bartkowicz (2011) przedstawiają problematykę w odniesieniu do przemian, które zachodziły w tych przestrzeniach, w małych miastach Polski południowo-wschodniej. W literaturze prezentowane są liczne studia przypadków (Kobylarczyk, 2005; Kuśnierz-Krupa i Krupa 2015; Hrehorowicz-Gaber, Węcławowicz-Bilska i Wójcikowski, 2019; Blazy, 2012; Ciepiela, 2019; Ciepiela, Kania i Łabuz, 2019), w tym związane z przekształceniami, jakim ulegały przestrzenie rynkowe w różnych okresach historycznych oraz jakie zachodzą w nich współcześnie. W odniesieniu do zmian mających miejsce w historycznych centrach miast w XX w. ciekawe ujęcie tematu zaprezentowano m.in. w pracy B. Szmygina (2000), w której zmiany te stanowią tło dla tworzenia doktryn z zakresu konserwacji zabytków. Pomimo bogatej literatury, w której przedstawiane są studia przypadków z terenu Polski południowo-wschodniej, stwierdzono, że jednie nieliczne publikacje dotyczą regionu świętokrzyskiego.

Współczesne przekształcenia w małomiasteczkowych rynkach polskich miast najczęściej realizowane są w ramach programów Unii Europejskiej, w których przeznaczane są środki finansowe, m.in. na wyrównywanie szans i rewitalizację miast (Ziobrowski, Ptaszycka-Jackowska, Rębowska i Geissler, 2000; Billert, 2006; Lorens, 2010). Rewitalizacja, zarówno w polskiej (Palicki, 2007; Węcławowicz-Bilska, 2012; Sumień, Furman-Michałowska, Ufnalewska i Wąs, 1989), jak i anglojęzycznej ${ }^{3}$ (Ramlee, Omar, Yunus i Samadi, 2015; Newman, 1995; Bristow i Jenkins, 2020) literaturze przedmiotu przyjmuje różne definicje, pojawia się także szereg zbliżonych pojęć. W Polsce od 2015 roku termin ten został zdefiniowany i uregulowany formalno-prawnie w Ustawie o rewitalizacji (2015).

Znaczna część przekształceń, które zachodzą w małomiasteczkowych rynkach, jest widoczna w skali całego miasta. W zależności od zasięgu i kompleksowości założeń projektowych zmiany te mogą stanowić swojego rodzaju rewolucję, całkowicie zmieniając kompozycję, użytkowanie, czy też odbiór i postrzeganie miejsca. W niniejszym artykule przedstawiono przykład rewitalizacji rynku w Osieku, prezentując stan z okresu przed rewitalizacją (2007 r.) i po rewitalizacji (2020 r.).

\footnotetext{
Wielkość małego miasta przyjęto zgodnie z klasyfikacją GUS (2012).

2 Choć w nielicznych przypadkach wykształciły się rynki dla handlu specjalistycznego (Przesmycka, 2009).

3 Np. regeneration, renewal, redevelopment, rehabilitation, conservation, restoration, reconstruction itd.
} 


\section{OSIEK ŚWIĘTOKRZYSKI - STUDIUM PRZYPADKU}

\subsection{CHARAKTERYSTYKA MIASTA}

Osiek ${ }^{4}$ położony jest w województwie świętokrzyskim, w powiecie staszowskim, w północno-zachodniej części Kotliny Sandomierskiej - Nizinie Nadwiślańskiej, zajmuje blisko 17,5 km². Rynek, przez który przebiegają drogi krajowa nr 79 i wojewódzka nr 765, znajduje się w centralnej części ośrodka.

Lokacja Osieka miała miejsce w 1430 r., na prawie magdeburskim, na mocy przywileju wydanego przez Władysława Jagiełłę (Sulimierski, Chlebowski i Walewski, 1886). Częste pożary, przemarsze wojsk, zmiany przynależności do różnych zaborów i liczne zniszczenia spowodowały stagnację i kryzys gospodarczy. Utarta praw miejskich w 1869 r. dodatkowo pogorszyła trudną sytuację ośrodka. Zniszczenie blisko 80\% zabudowy i wysiedlenia ludności, jakie miały miejsce w wyniku prowadzonych działań, w trakcie II wojny światowej, spowodowały, że stopniowa odbudowa społeczności miejskiej zaczęła się dopiero w latach 60. i 70. XX wieku. Uruchomienie kopalni siarki i związane z tym odzyskanie praw miejskich w 1994 r. wpłynęło w niewielkim stopniu na rozwój ośrodka. Obecnie w Osieku dominuje sektor rolniczy i przemysłowy ${ }^{6}$. Przewidywane w Studium uwarunkowań i kierunków zagospodarowania przestrzennego, przyjętym uchwałą nr XVI/108/2020 Rady Miejskiej w Osieku z dnia 28 lutego 2020 r., główne kierunki rozwoju dotyczą terenów o funkcji mieszkaniowej. Chcąc stworzyć reprezentacyjną przestrzeń publiczną stanowiącą równocześnie miejsce dla życia społecznego, w 2007 r. władze lokalne podjęły decyzję o przystąpieniu do rewitalizacji rynku, którą przeprowadzono w latach 2009-2010. Przebudowa tej przestrzeni była zrealizowana w ramach projektu: „Rewitalizacja Miasta Osiek - etap I - rozebranie dawnego budynku restauracji - na płycie rynku i przebudowa rynku", sfinansowanego z udziałem funduszy europejskich przyznanych na lata 2007-2014.

\subsection{RYNEK WSPÓŁCZEŚNIE}

Rynek zajmuje około 150 × 170 m, z niewielkim poszerzeniem w północnej części. W centralnym obszarze widoczne są różnice w wysokości. Istotne zróżnicowanie w poziomach terenu występuje również za linią zabudowy wschodniej pierzei, gdzie teren opada w kierunku wschodnim.

Zabudowa rozmieszczona wokół rynku, zarówno przed rewitalizacją, jak i obecnie, tworzy niepełne pierzeje. Wśród tych obiektów zachowały się nieliczne budynki o wartościach historycznych (il. 1, 2). Są to domy jednokondygnacyjne, z dwuspadowymi lub naczółkowymi dachami, o symetrycznym kącie nachylenia połaci. Dachy kryte są głównie dachówką

4 Liczba mieszkańców wg GUS, stan: 31.12.2020 r.

5 Decyzja o budowie oddziału kopalni siarki w Osieku zapadła w 1984 r. (Grupa Azoty, 2019).

6 W sektorze rolniczym jest zatrudnionych $44,7 \%$ mieszkańców miasta, $25,7 \%$ pracuje w przemyśle i budownictwie, a 7,2\% w sektorze usługowym (GUS, 2020). 


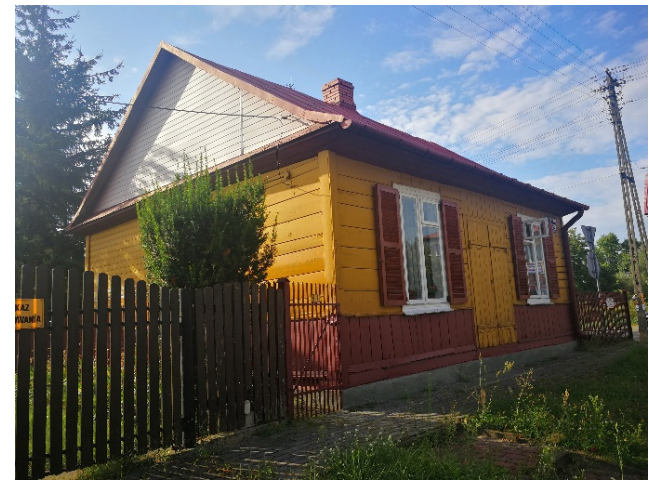

II. 1. Budynek historyczny usytuowany we wschodniej pierzei rynku. Fot. autorka, 2020

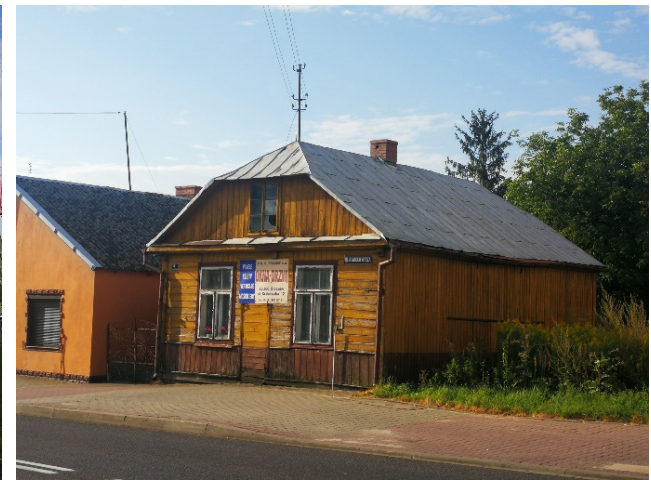

II. 2. Budynek historyczny usytuowany w południowej pierzei rynku. Fot. autorka, 2020

w kolorze szaro-brązowym. Elewacje wykończono okładziną drewnianą, w ciepłych kolorach. Górne części ścian malowane są w kolorze pomarańczowym, z brązowym pasem o odmiennym układzie deskowania, podkreślającym dolną linię okien.

Większość budynków tworzących pierzeje przyrynkowe to obiekty XX-wieczne, nienawiązujące gabarytami ani geometrią dachów do zabudowy tradycyjnej, najczęściej dwukondygnacyjne (il. 3). Wyróżnia się trójkondygnacyjny budynek urzędu (il. 4), znacznie cofnięty w stosunku do historycznej linii zabudowy. Elewacje tego obiektu są tynkowane i malowane, z rytmicznym podziałem okien. Pasy okienne podkreślono kolorem bladoróżowym.

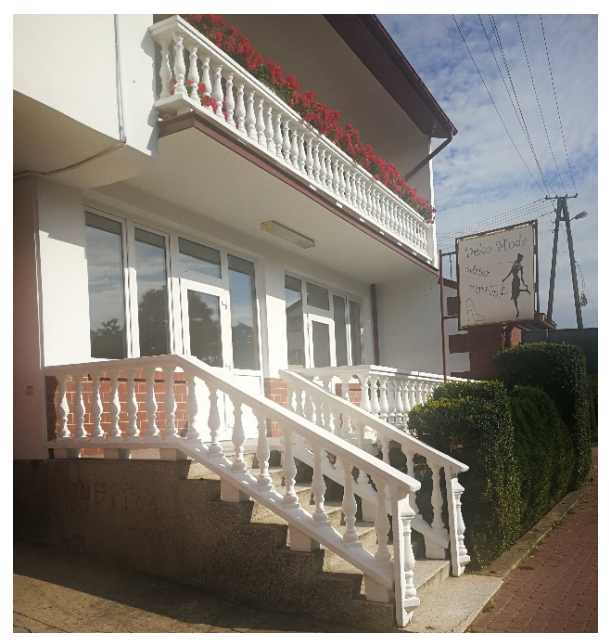

II. 3. Budynek XX-wieczny usytuowany w zachodniej pierzei rynku.

Fot. autorka, 2020

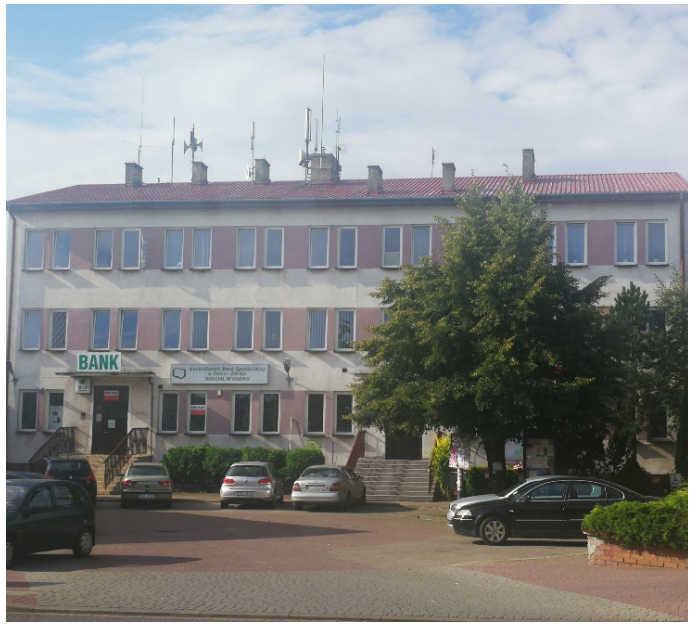

II. 4. Budynek XX-wieczny usytuowany w centralnej części południowej pierzei rynku. Fot. autorka, 2020 


\subsection{RYNEK PRZED REWITALIZACJA}

Centralna część rynku była terenem trudno dostępnym. Od strony zachodniej oddzielona od pierzei drogą wojewódzką, od południa krajową - dla pieszych była dostępna jedynie od strony północy i południowego wschodu - dzięki wyznaczonym przejściom. Dodatkowe ograniczenie i uciążliwość stanowił intensywny ruch samochodowy. Główne ciągi piesze przebiegały wzdłuż pierzei zabudowy.
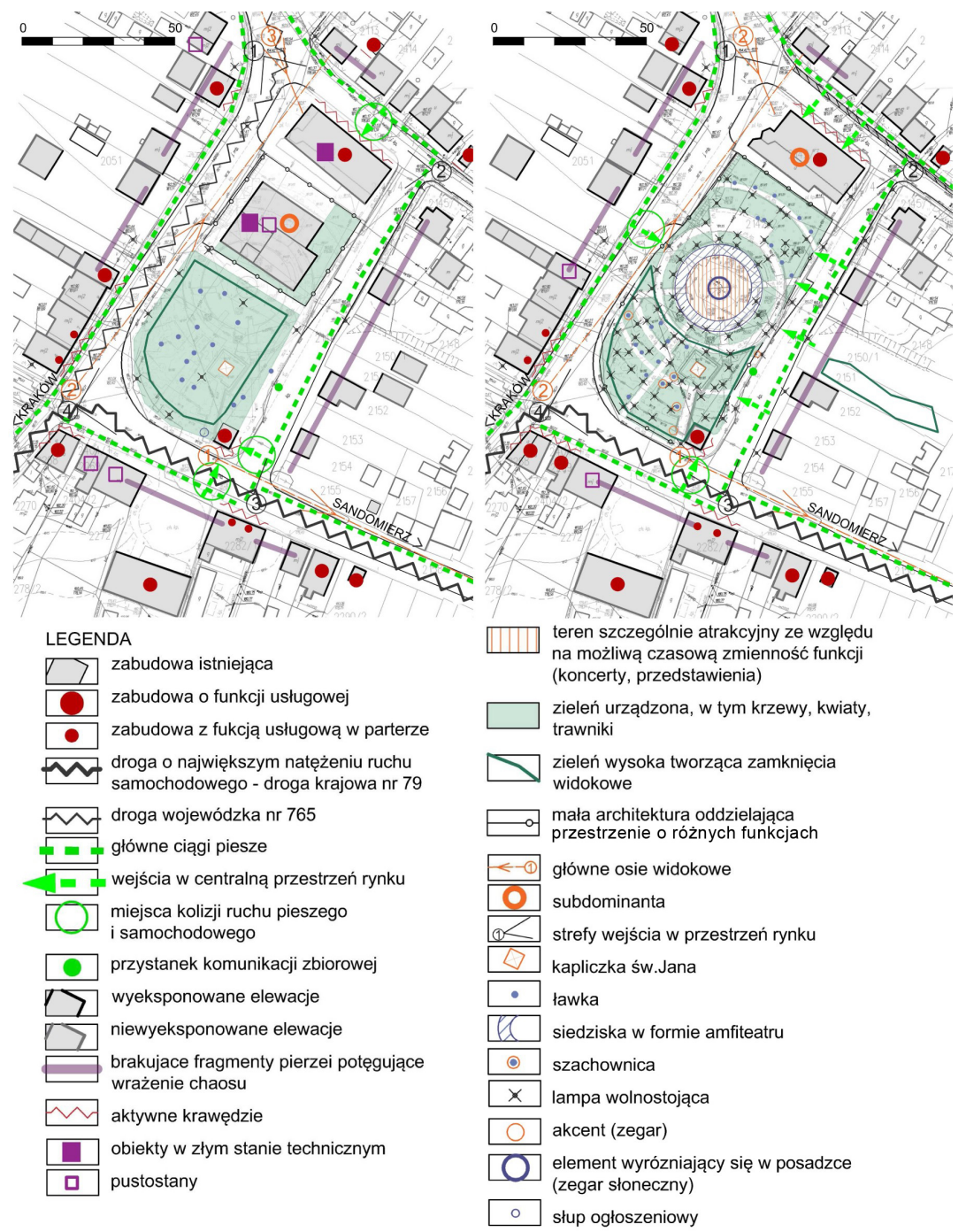

II. 5. Schemat zagospodarowania rynku w Osieku przed rewitalizacją i po rewitalizacji. Oprac. własne 
Wśród zabudowy przyrynkowej proporcje zabudowy mieszczącej funkcje usługowe i mieszkalne były zbliżone, z nieznaczną przewagą funkcji handlowych i usługowych (o charakterze podstawowym), sytuowanych zarówno w parterach obiektów mieszkalnych, jak i w postaci obiektów wolno stojących. Północną część płaszczyzny ryku zajmował obiekt usługowy, a centralną zdegradowany pustostan. W części południowej znajdowała się zieleń urządzona wysoka (il. 5).

Zieleń wysoka z południowej części rynku przesłaniała częściowo subdominantę, którą stanowił komin (obiektu w stanie zdegradowanym: il. 6). Forma zabudowy w centralnej części rynku, brakujące fragmenty pierzei, zaniedbana zieleń, pustostany i nieuporządkowana zabudowa tworzyły wrażenie chaosu. Brakowało miejsca reprezentacyjnego, przestrzeni dla życia społecznego i kulturalnego, z którym mogliby utożsamiać się mieszkańcy miasta.

\subsection{RYNEK PO REWITALIZACJI}

Dostępność piesza centralnej części rynku uległa zmianom w stosunku do okresu sprzed 2007 r. Po zrealizowaniu obwodnicy w trasie drogi wojewódzkiej zdecydowanie został ograniczony ruch samochodowy wzdłuż zachodniej, wschodniej i północnej pierzei rynku. Dostęp do części centralnej uległ poprawie, zwłaszcza od północy i wschodu. Nie wyznaczono tu nowych przejść dla pieszych, jednak poprzez stosowne oznaczenie i zmianę nawierzchni utworzono ciąg pieszo-jezdny, umożliwiający swobodne przemieszczanie się. Układ i kompozycja zieleni umożliwiły stworzenie kilku „wejść” w centralną strefę rynku. Główne ciągi piesze w obrębie rynku nadal przebiegają, przede wszystkim, wzdłuż pierzei zabudowy.

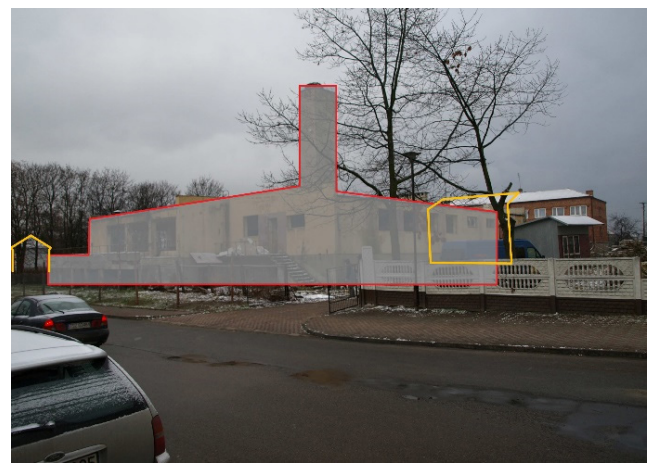

II. 6. Widok centralnej części rynku z okresu sprzed rewitalizacji, z oznaczonym czerwonym obrysem budynkiem restauracji i żółtymi obrysami - kapliczki i jednego z domów mieszkalnych usytuowanych w zachodniej pierze (Ciepiela, 2021)

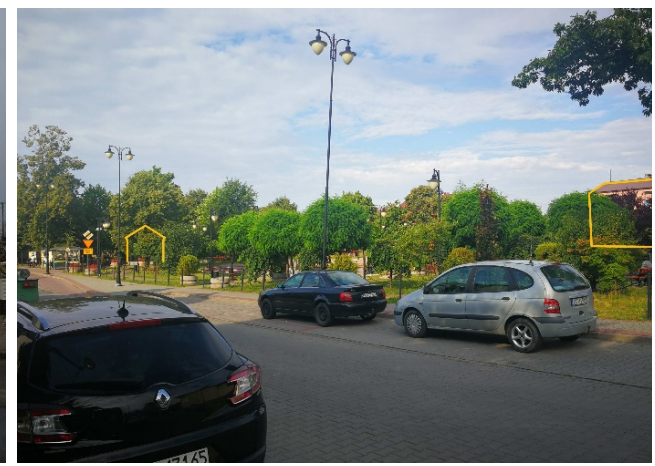

II. 7. Widok centralnej części rynku z okresu po rewitalizacji, z oznaczonymi żółtymi obrysami - kapliczki i jednego z domów mieszkalnych usytuowanych w zachodniej pierzei. Teren placu miejskiego otoczony zielenią nie jest wyeksponowany (Ciepiela, 2021) 
Ilość funkcji usługowych rozmieszczonych wśród zabudowy przyrynkowej zmalała w stosunku do okresu sprzed rewitalizacji. Nie zmienił się również ich charakter, nadal przeważają funkcje usługowe o znaczeniu podstawowym. Przebudowano pawilon handlowy w północnej części rynku (na obiekt usługowy), który stał się nową subdominantą. Rozbiórka pustostanu i uwolnienie centralnej części umożliwiły wydzielenie placu miejskiego (il. 5-7).

Zieleń wysoka w południowej części rynku została zakomponowana i uporządkowana. W centralnej części utworzono amfiteatralnie zagłębiony plac otoczony zielenią, co znacznie zmieniło charakter przestrzeni. Oryginalny kształt współśrodkowych kół nie jest związany z tradycyjnym rozplanowaniem rynków miejskich. Forma zagospodarowania terenu spowodowała przywrócenie mu reprezentacyjnego charakteru (il. 8, 9). W stosunku do okresu sprzed rewitalizacji znacznie wzrosła liczba obiektów małej architektury.

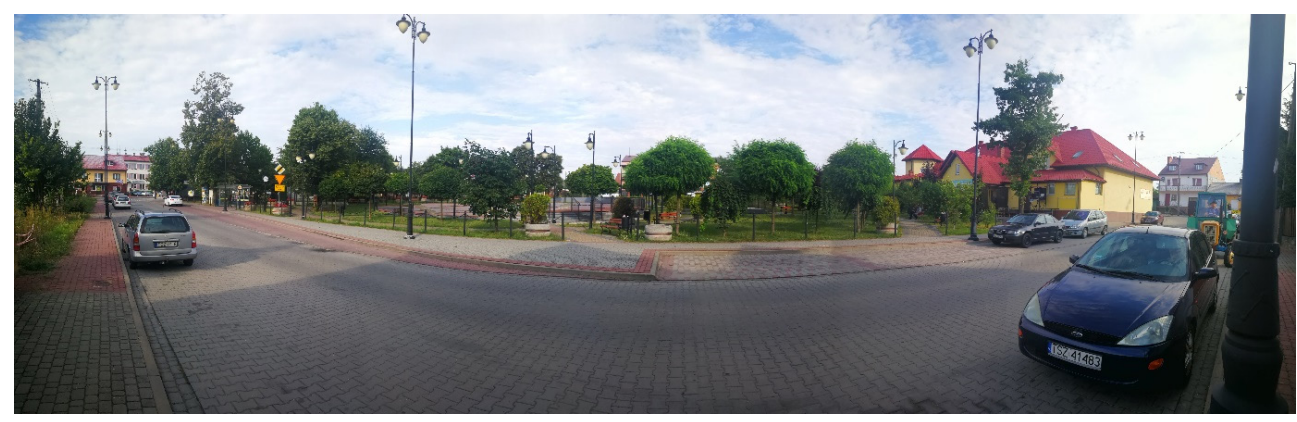

II. 8. Widok rynku od strony wschodniej. Fot. autorka, 2020

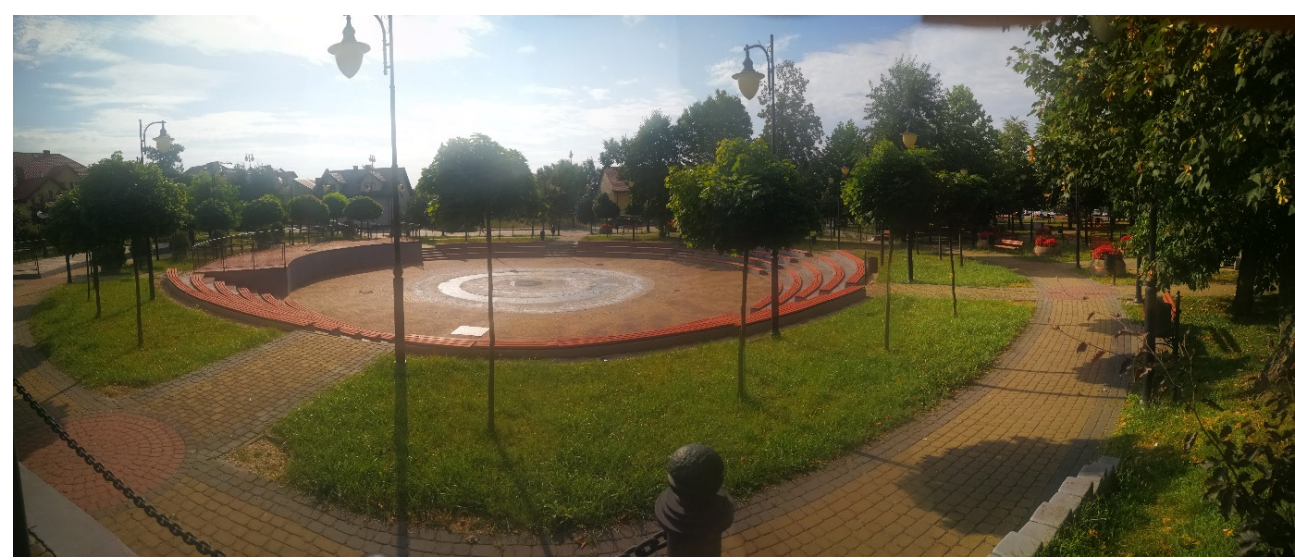

II. 9. Widok centralnej części rynku od strony wschodniej. Fot. autorka, 2020 


\section{PODSUMOWANIE}

Wyniki przeprowadzonych analiz wykazały, że nowa forma zagospodarowania centralnej części rynku w Osieku spowodowała krystalizację układu przestrzeni publicznych w mieście. Projekt zrealizowano na podstawie konkursu ofert ${ }^{7}$, co niewątpliwie zaważyło na jakości przyjętych rozwiązań kompozycyjnych i funkcjonalnych. Silne założenie kompozycyjne, w postaci koncentrycznych kręgów, nie nawiązuje ani do topografii terenu, ani do uwarunkowań historycznych czy kulturowych. Projekt przebudowy nie obejmował zabudowy przyrynkowej, która w istotny sposób wpływa na odbiór i postrzeganie przestrzeni. Silnie zróżnicowane gabaryty i kolorystyki budynków nadal tworzą wrażenie chaosu. Jednakże, jak wskazują wyniki badań, proces rewitalizacji przeprowadzony w Osieku umożliwił wykształcenie przestrzeni, jakiej dotychczas w mieście brakowało. Poprawiła się dostępność centralnej części rynku i przede wszystkim w istotny sposób zmieniło się jego zagospodarowanie. Wyburzono zdegradowany obiekt stanowiący subdominantę, a w jego miejscu powstał amfiteatralnie zagłębiony plac.

Podsumowując, należy podkreślić, że rynek w obecnej formie stanowi reprezentacyjną przestrzeń i wizytówkę miasta, pozostając równocześnie ważnym dla lokalnej społeczności miejscem spotkań i wypoczynku.

\section{BIBLIOGRAFIA}

Bartkowicz, B. (2011). Rola planowania przestrzennego w konkretyzacji zadań strategicznych przemian i aktywacji przestrzeni. Czasopismo Techniczne, 108(10), 1-A, 7-13.

Billert, A. (2005). Problemy rewitalizacji miast - skrypt dla studentów Studium Gospodarki Przestrzennej Rozwoju i rewitalizacji miast i obszarów miejskich UAM Collegium Polonicum w Słubicach. Słubice.

Blazy, R. (2012). Aktywność społeczna jako najważniejsza treść rewitalizacji miasta. Czasopismo Techniczne, 109(12), 3-A, 173-180.

Bristow, R.S., Jenkins, I.S. (2020). Geography of fear: Fright tourism in urban revitalization. Journal of Policy Research in Tourism, Leisure and Events, 12(2), 262-275. https://doi.or g/10.1080/19407963.2019.1631319

Ciepiela, A. (2019). Reinstanation the Significance of City Main Public Space - Revitalization of the Main Square in Polaniec. W: $3^{\text {rd }}$ World Multidisciplinary Civil Engineering-Architecture - Urban Planning Symposium. Prague.

7 „Wg informacji uzyskanych z UM w Osieku z dnia 20.01.2020 r. projekt przebudowy rynku został zlecony w drodze konkursu ofert zgodnie z ustawą o zamówieniach publicznych (gdzie głównym kryterium była najniższa cena)" (Ciepiela, 2021). 
Ciepiela, A. (2021). Współczesne zmiany głównych przestrzeni publicznych w miastach małych województwa świętokrzyskiego w aspekcie rewitalizacji (praca doktorska). Kraków.

Ciepiela, A., Kania, O., Łabuz, R. (2019). W: M. Wdowiarz-Bilska (red.). Małe miasta o układach historycznych w Polsce Południowej. Kraków: Wydawnictwo Politechniki Krakowskiej.

Grupa Azoty. (2019). Siarkopol z odnowioną koncesją na złoże siarki Osiek. Pobrane z: https:// grupaazoty.com/aktualnosci/siarkopol-z-odnowiona-koncesja-na-zloze-siarki-osiek (dostęp: 07.12.2021).

Główny Urząd Statystyczny. (2020). Osiek w liczbach. Pobrane z: https://www.polskawliczbach. pl/Osiek (dostęp: 07.12.2021).

Główny Urząd Statystyczny. (2012). Miasta w liczbach 2012. Basic Urban Statistic. Pobrane z: https://stat.gov.pl/files/gfx/portalinformacyjny/pl/defaultaktualnosci/5499/3/7/1/ miasta_w_liczbach_2012_07_31_internet.pdf (dostęp: 07.12.2021).

Hrehorowicz-Gaber, H., Węcławowicz-Bilska, E., Wójcikowski, W. (2019). Karpackie miasta, miasteczka i wsie. Kraków: Wydawnictwo Politechniki Krakowskiej.

Kobylarczyk, J. (2005). Rola rynku w kształtowaniu przestrzeni publicznej na przykładzie Jarosławia. Czasopismo Techniczne, 9-A, 263-272.

Kuśnierz-Krupa, D., Krupa, M. (2015). Zmiany w aranżacji placów rynkowych miast lokacyjnych w Polsce południowo-wschodniej po 1945 roku (na wybranych przykładach). Wiadomości Konserwatorskie, 41, 49-58.

Lorens, P. (2010). Rewitalizacja miast. Planowanie i realizacja. Gdańsk: Wydawnictwo Politechniki Gdańskiej.

Newman, O. (1995). Defensible space: A new physical planning tool for urban revitalization. Journal of the American Planning Association, 61(2), 149-155. https://doi. org/10.1080/01944369508975629

Palicki, S. (2007). Rewitalizacja na tle innych przejawów odnowy miast. Studia i Materiały Towarzystwa Naukowego Nieruchomości, 15, 1-2, 189-197.

Przesmycka, E. (2001). Przeobrażenia zabudowy i krajobrazu miasteczek Lubelszczyzny. Lublin: Wydawnictwo Politechniki Lubelskiej.

Przesmycka, E. (2009). Rynki małych miast Polski południowo-wschodniej wczoraj i dziś. Architektura Krajobrazu, 2, 48-56.

Ramlee, M., Omar, D., Yunus, R.M., Samadi, Z. (2015). Revitalization of urban public spaces: An overview. Procedia-Social and Behavioral Sciences, 201, 360-367. https://doi. org/10.1016/j.sbspro.2015.08.187

Sulimierski, F., Chlebowski, B., Walewski, W. (1886). Słownik geograficzny Królestwa Polskiego i innych krajów słowiańskich. T. VII. Pobrane z: http://dir.icm.edu.pl/pl/Slownik_ geograficzny (dostęp: 13.11.2020).

Sumień, T., Furman-Michałowska, J., Ufnalewska, K., Wąs, W.(1989). Odnowa miast europejskich. Warszawa: Instytut Gospodarki Przestrzennej i Komunalnej. 
Szmygin, B. (2000). Kształtowanie koncepcji zabytku i doktryny konserwatorskiej w Polsce $w X X$ w. Lublin: Wydawnictwo Politechniki Lubelskiej.

Ustawa z dnia 9 października 2015 o rewitalizacji (Dz. U. 2015 poz. 1777 t.j.).

Węcławowicz-Bilska, E. (2015). Podstawowe rodzaje inwestycji realizowanych w ostatnim dziesięcioleciu w przestrzeni małych miast Małopolski. Acta Universitatis Lodziensis. Folia Geographica Socio-Oeconomica, 19(1), 3-19.

Węcławowicz-Bilska, E. (2012). Współczesne tendencje rewitalizacji miast europejskich. Czasopismo Techniczne, 3-A, 19-26.

Ziobrowski, Z., Ptaszycka-Jackowska, D., Rębowska, A., Geissler, A. (2000). Rewitalizacja. Rehabilitacja. Restrukturyzacja. Odnowa miast. Kraków: IGPiK O.

Zmiana Studium Uwarunkowań I Kierunków Zagospodarowania Przestrzennego Gminy Osiek, przyjęta uchwałą nr XVI/108/2020 Rady Miejskiej w Osieku z dnia 28 lutego 2020 r. 